\title{
What isn't said
}

It starts with me sitting in this little pink room and him telling me I have inflammatory breast cancer, and he can't look at me. Then the nurse is grabbing my arm at the elevator, and I plead with her to let go, and she lets go, and I go home, and I fall apart, and I make phone calls in between gasping for air ... ${ }^{1}$

$\mathrm{F}$ our years later, I'm wondering if things could have gone differently for me if the physician had looked at me when he gave me my diagnosis. Would I have let the nurse guide me back into the office? Would I have fallen apart less? Would I have been gasping less for air? Would I have wanted to fight for my life?

Nonverbal communication no. 1: When I received my diagnosis on Oct. 26, 2010, it went something like this: "You have an aggressive form of breast cancer called inflammatory breast cancer. You will need to start treatments immediately ... blah blah blah." I heard "blah blah blah" for two reasons. First, the physician did not look at me. In fact, he turned away and spoke to the ground. Because of this, I had a hard time hearing what he was saying. Second, his speaking to the ground told me that whatever he was saying was so horrific that he couldn't look me in the eye, and I stopped listening. I felt deep within that his actions reflected what he thought my outcome would be: horrific.

Result: I decided this battle wasn't worth fighting, that I should walk away and live whatever life I had left. But I couldn't help recalling the physician speaking to the floor, and I wondered why my life, which had changed forever, wasn't worth more to him. Why couldn't he look me in the eye when he spoke? I felt like I was going to die tomorrow.

Nonverbal communication no. 2: I met my oncologist and resident oncologist. The resident oncologist was wel-

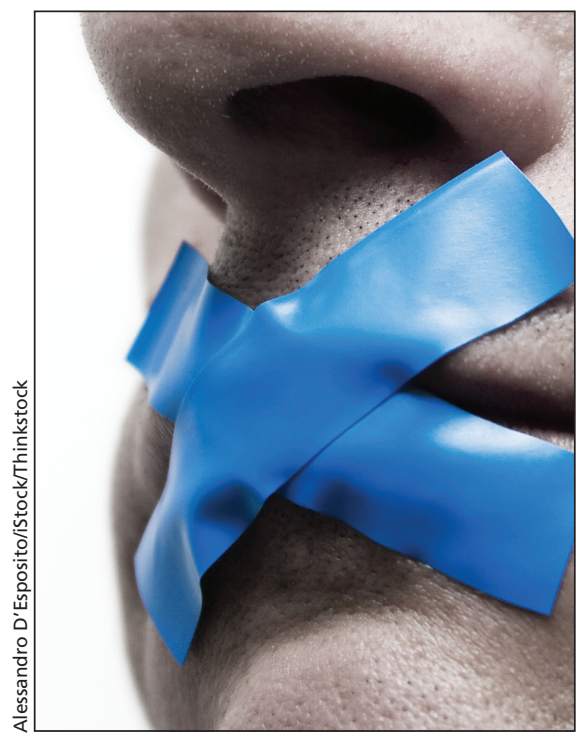

coming and calm, he looked at me when he spoke, and he was present during our conversations. The oncologist entered the room by first poking his head around the drape making it look as if he was just a floating head with a smile that seemed to touch both ears.

Result: I was open to exploring treatment options. Why would this resident oncologist be so calm if I was going to die? Why would this oncologist be so happy if my situation was all doom and gloom? I felt there was hope.

Nonverbal communication no. 3: I was laying on the operating table feeling less than human, like a body before an autopsy. The room was filled with masks, crossed arms or averted faces. Their apparent boredom suffocated me, and I hoped I would never wake up. Without a word of explanation, a faceless man removed my cloth headband. I wanted to hit him. The headband was covering my bald head that I had yet to accept; he had glibly stripped away a piece of my dignity. The surgeon approached, took the headband and gently placed it back on my head. Neither of them said a word; one action had been abrupt, the other gentle. The surgeon then took my hand as the anesthesiologist injected pain blockers into my back; she didn't flinch as I squeezed hard hoping to lessen some of my physical and emotional pain.

Result: I hope I never become so desensitized that I exhibit such boredom in the presence of someone else's nightmare. The surgeon brought me back to life when I felt like I was dead.

Nonverbal communication no. 4: My radiation oncologist smiled when she entered the room. We went through the standard question-and-answer period, and then I told her I wasn't able to tolerate a certain drug meant to increase my odds for survival. She lifted her arm and rested her elbow on the examining table beside her. I was in a chair across from her, watching as she brought her hand up to her cheek and let her head rest into it as her eyes went down to the ground. I could tell she was absorbing what I'd said. I could tell she was sad to hear I couldn't tolerate that drug, I could tell she cared.

Result: I decided I would find a way to increase my odds for survival with something that might mimic that drug.

The difference between a compliant patient and a distressed one is often as simple as eye contact, as human as a touch: what isn't said tells more than any words.

\section{Caloren Johnstone}

Ottawa, Ont.

\section{Reference}

1. Johnstone C. The pink room. CMAJ 2012;184:565.

CMAJ 2015. DOI:10.1503/cmaj.141380 